\title{
UIS CAVE SYMBOLS: THE DEFINITIVE LIST
}

\section{JAMSKI SIMBOLI MEDNARODNE SPELEOLOŠKE ZVEZE: KONČNI SEZNAM}

PHILIPP HÄUSELMANN ${ }^{1}$

${ }^{1}$ Geological Institute, University of Bern, Baltzerstr. 1,3012 BERN, SWITZERLAND, praezis@geo.unibe.ch 


\section{Philipp Häuselmann: Jamski simboli Mednarodne speleološke zveze: Končni seznam}

Predstavljen je seznam jamskih simbolov, ki jih Mednarodna speleološka zveza priporoča pri risanju načrtov podzemnih jam. Seznam simbolov so leta 1999 izvolili delegati iz dvanajstih držav. Kjer je potrebno, je poleg simbola še krajša razlaga. V prispevku je na kratko predstavljena tudi podkomisija za topografijo pri Mednarodni speleološki zvezi.

Ključne besede: jamsko kartiranje, seznam simbolov, Mednarodna speleološka zveza.

\section{Abstract}

UDC: 528.9:551.44

\section{Philipp Häuselmann: UIS Cave Symbols: The definitive List}

A set of cave symbols used for underground mapping has been voted by national delegates of 12 countries in 1999. This symbol set is shown and, when necessary, explained. The UIS subcommission on topography is briefly presented and its aims outlined.

Key words: cave mapping, symbol set, UIS. 


\section{INTRODUCTION}

At the "Second International Meeting on subterrainean Topography" in Breitenbach (Switzerland), 1995, Cave Signature lists of different countries had been the subject of discusssion. The essential symbols in use (Fabre et al. 1978; Müller 1980; Grossenbacher 1992) had been integrated into a new list and published as a proposal of an international cave signature list. This proposal has been debated thoroughly at the UIS congress in La Chaux de Fonds 1997 and then voted and accepted by the national delegates of each country.

This list should be a comprehensive, international foundation, on which each country can, if necessary, introduce their own additional symbols. It is therefore not forbidden to use additional meaningful symbols.

Among active surveyors and draftsmen it turned out, that the plan with all its symbols and signatures is only "half" of the work of, documenting a cave system. The other, also very important part is a comprehensive description of the system, including phenomena that cannot be sketched in a map. The written cave description therefore is a very important factor in documenting the cave. Observing geology, sediments, climatic conditions, hydrology as well as watching fauna and flora, describing the location and path to the cave entrance, an abstract on the history of exploration, last not least lists on needed equipment; all these points belong to a comprehensive cave documentaion. Assumptions on continuations of galleries, just as theories on the genesis of a certain passage round up the cave description and form together with a well done cave map a valuable foundation for further work.

It is therefore recommended, not only to sketch a cave plan and a developed section (see Dériaz 1991), but also to make the cave description mentioned above.

The presented symbol list can be viewed and downloaded at:

http://www.karto.ethz.ch/neumann-cgi/cave_symbol.pl

\section{EXPLANATIONS ON THE LIST}

The symbols that have been already in use for a long time ("as before") and that have not been changed have no explanation here.

Main survey points: The main survey points have been kept in the list, but often they are no longer shown on fair copies.

Underlying passages: As an additional help to distinguish the lower from the upper passage it is recommended to stop the line of the lower gallery before it reaches the upper gallery. To distinguish this symbol from the "presumed dimensions of space" (see below) it is recommended to draw short dashes with wide spacing.

Presumed dimensions of space: as before. The dashes should be long and the spacing narrow (see "underlying passages").

Ceiling form: The symbol for the form of the ceiling of a cave is also used for the dripline and for chimneys.

Dripline: The dripline can give valuable information especially for smaller caves and overhangs. It describes the actual entrance to a cave including the upper ceiling region and should therefore not be omitted. At the dripline the cave begins. 


\section{Cave Symbols - The official UIS Symbol List (State 1999 - voted by the national delegates)}

Main Measuring Points

Outline of a gallery

Underlying galleries

Too narrow continuation

Continuation possible

Presumed dimensions of Space

Ceiling form
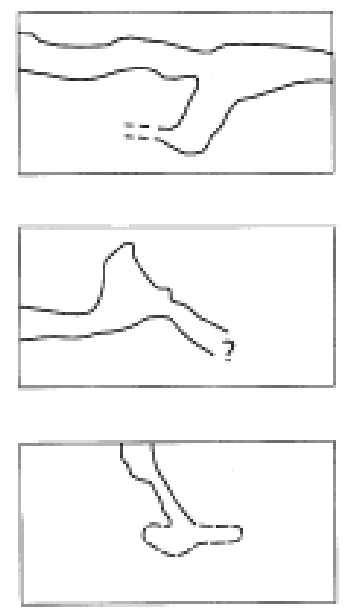

Plan
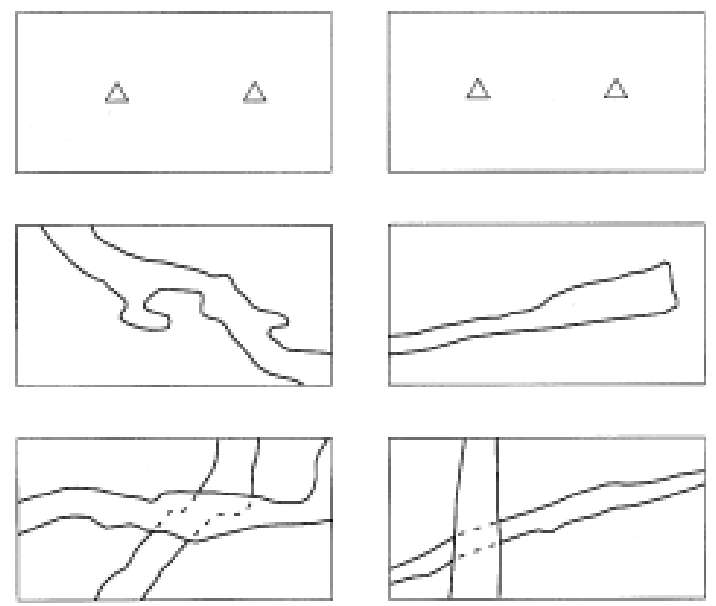

Section
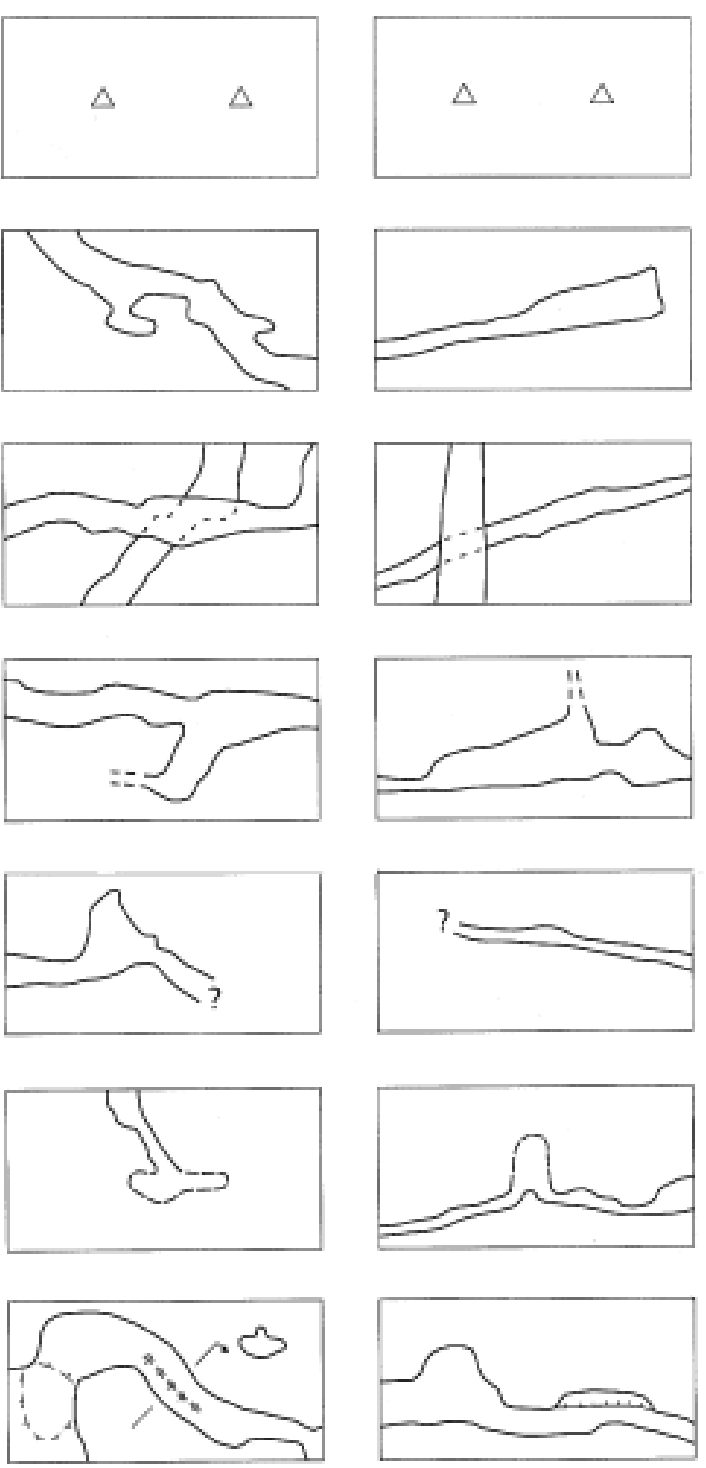


\section{Cave Symbols - The official UIS Symbol List (State 1999 - voted by the national delegates)}

Dripline

(beginning of the cave) -

Profile

(arrow in line of view)

Step

(height in meters)

Pit

(depth in meters)

Pit open to the surface

Chimney - Chimney-Pit

Contourlines

(altitude in meters) -

Gradient arrows

Entrance arrow

Gradient Lines

Altitude above Sealevel
Plan
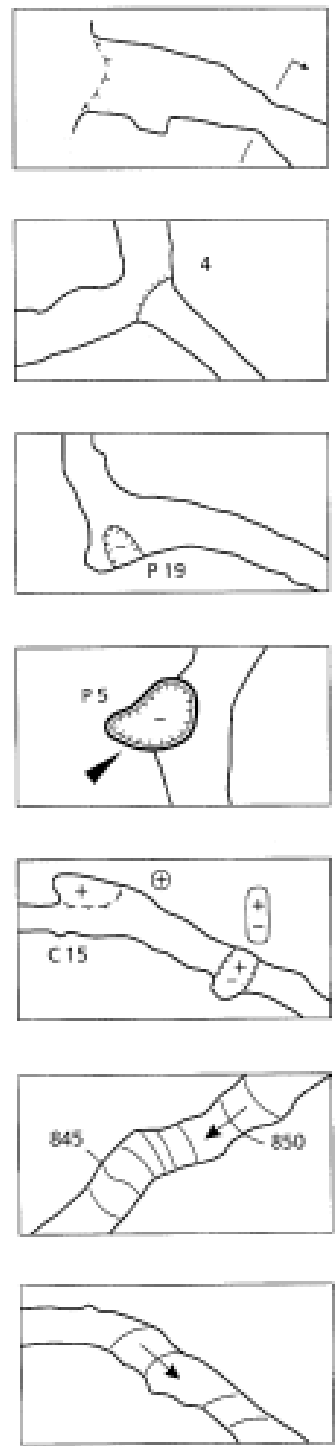
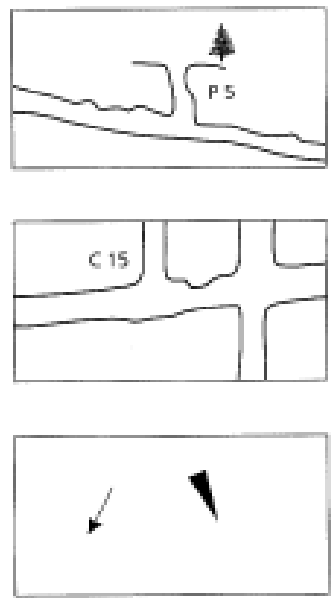

Section
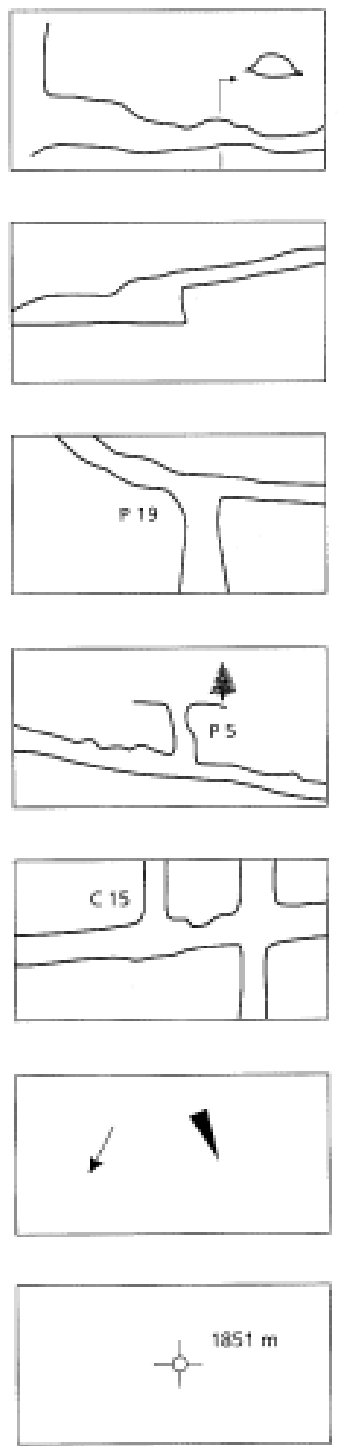
Cross-section: Cross-sections are of major importance for the understanding of a passage. For each map passage cross-sections must be drawn. The arrows indicating the direction of view are done differently, a clear indication is, however, necessary.

Steps: This symbol is well known, just do not forget that the little dashes are always to be orientated downwards.

Pitches: The filled or empty triangle has been replaced by dashed lines for two reasons: First, the dashed line is easier to draw, secondly it is unclear even to most draughtsmen whether the empty triangles represent the smaller or the higher steps or when they should be filled (at $5 \mathrm{~m}$ or $10 \mathrm{~m}$ ?).

Aven / Aven-pitches: The plus and minus signs can be written inside or outside the cave. For reasons of clearness they should be encirced when written outside the cave.

We agreed to the following procedure to indicate the depth of a drop or a pitch: If the drop can be climbed without gear, there is only the number (in meters) written. If gear is needed, any letter precedes the number. This way, the use of most countries is respected. It is optional to draw the anchor points and ropes into the longitudinal section.

Isohypses: Isohypses (lines of same altitude) with altimetric measurement as done on geographic maps are seldom used, as the exact ground level is not always easily established and precise drawings can cause serious problems. Gradient lines are used more frequently.

Gradient arrows: The differentiation between gradient arrows inside and outside the cave is now omitted. An arrow indicating the entrance was added to the list.

Gradient lines: Gradient lines are the most common way of illustrating the ground structure. As on geographic maps, narrow spacing indicates a steep and wide spacing a gentle slope.

Altitude above sea-level: This symbol has also been kept for reasons of consistency and designates the altitude above sea-level used in the map. It is highly recommended to write $1880 \mathrm{~m}$. instead of just writing 1880. Generally maps are all to be done in SI units.

Joint, fault, bedding plane: These symbols can be quite important for the understanding of the cave. It is recommended not to use these symbols unless one is totally sure about their nature. The arrow connecting two joint symbols is normally only used in the plan. It shows whether a cave longitudinal sections a joint several times or whether it follows the joint itself.

Sump: as before. As an option it is possible to stop the crosshatching in order to draw the characteristics of the sump. This possibility, especially useful in longer sumps, is also shown.

Cascade / waterfall: The symbol for waterfall is the same as the one for drop. To show flowing water one can draw an arrow indicating the flow before or at the side.

Spring / sink: Springs or sinks which flow sideways in or out of a cave do not need a half circle to be characterised, whereas water inlets and outlets in the ground should be marked with a half-circle to distinguish them clearly from normal flowing water.

Widespread water inlet: There is no special symbol any more. It is necessary to draw several \pm parallel arrows indicating the flow.

Seeping of a water course in a sediment: Here, the semicircle is also used in the plan. In the longitudinal section the direction of the arrow can be bent towards the bottom to hint the seeping.

Symbols for temporary waters of all kinds have been omitted allogether because of the following reasons: Hydrologically many water courses are also dry in dry times and are therefore also temporary. Adding to that, there have been many different symbols in the old symbol lists that would severely extend this list. One may add a note on temporary waters to the cave description. 


\section{Cave Symbols - The official UIS Symbol List (State 1999 - voted by the national delegates)}

Difference in Elevation
(height in meters)
Joint - Fault - Inclined Joint




\section{Cave Symbols - The official UIS Symbol List (State 1999 - voted by the national delegates)}

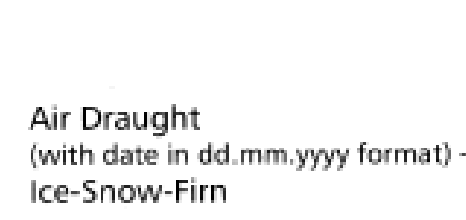

(with date in dd
Ice-Snow-Firn

Stalagmites

Stalactites

Sinter Curtains

Pillars

Helictites -

Soda Straws -

Crystals

Sinter Pools

Flowstone Wall Calcite Moonmilk
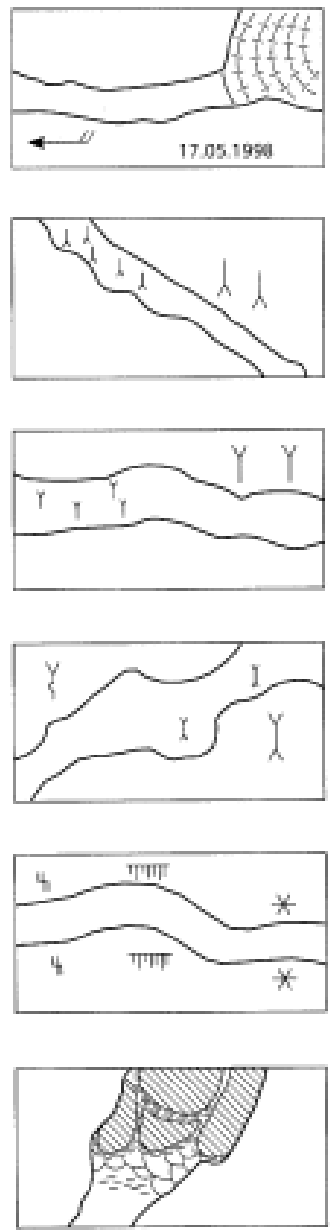

Section
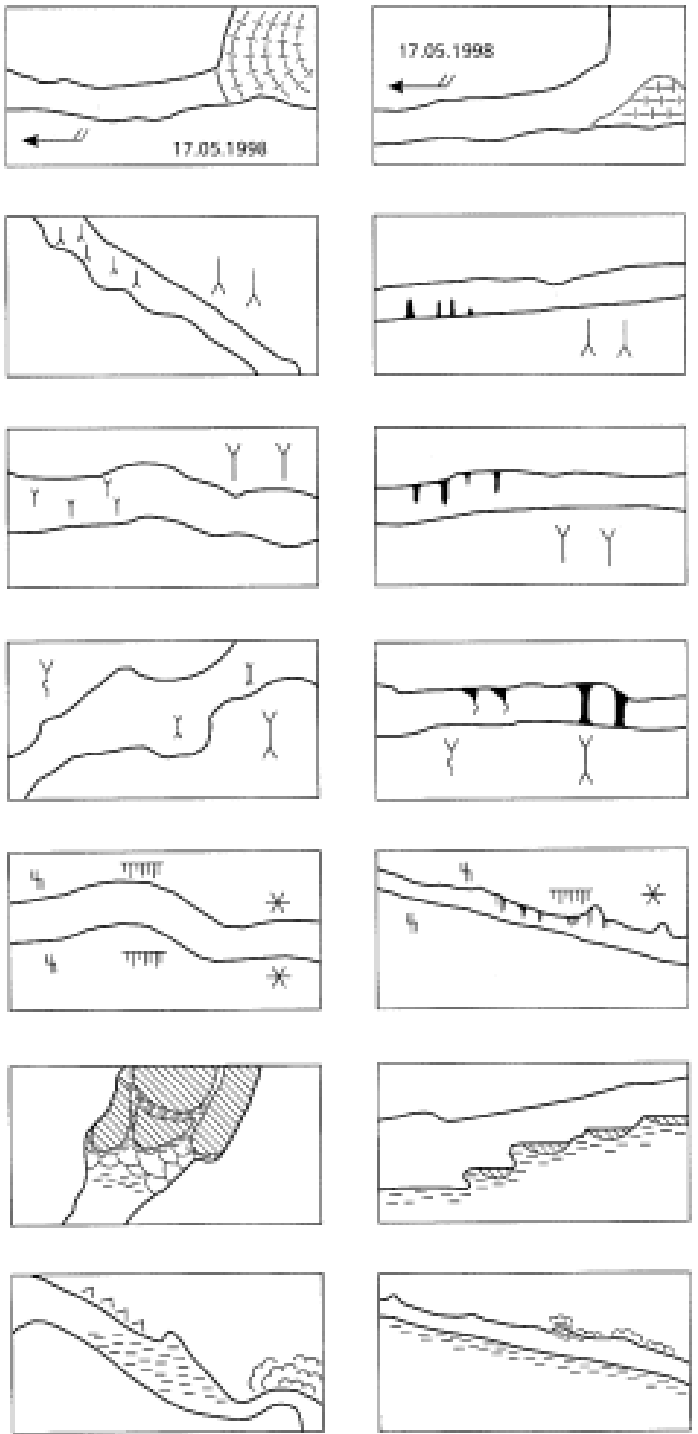


\section{Cave Symbols - The official UIS Symbol List} (State 1999 - voted by the national delegates)

\begin{abstract}
North Arrow - Geographic Cartesic and Magnetic
\end{abstract}

Blocks -

Debris

Pebbles

Clastic sediments -

Sand-Silt-Clay-Humus

Plan
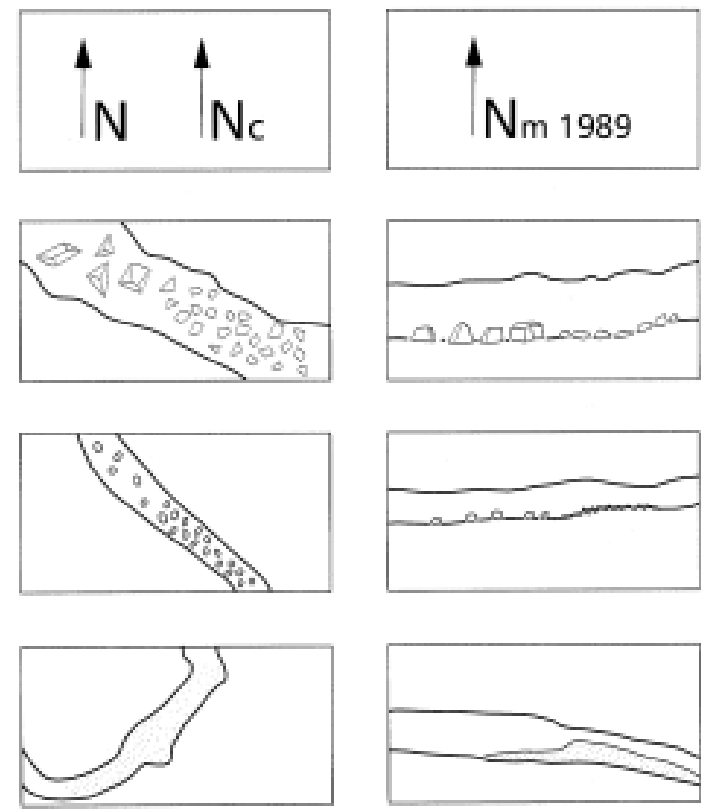

Claycovered Walls
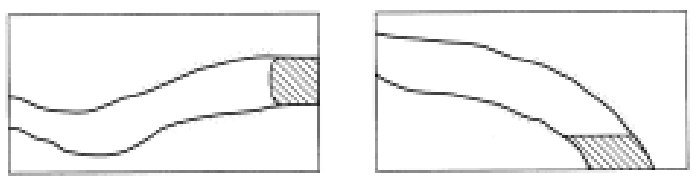

Guano
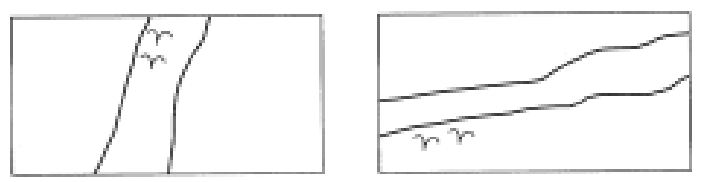

Camp
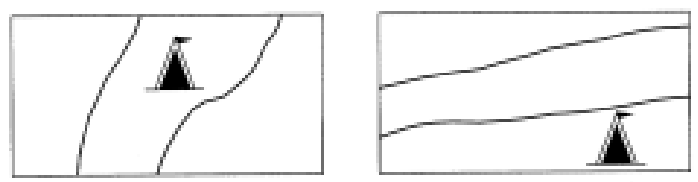
Flow casts (Scallops): The arrow has been omitted.

Paleoflow: This very useful symbol has been added. It is not only of use with scallops, but also with ripple marks, imbrications and other features. In addition it might be used in lava caves to show the flow direction of the lava.

Flute: The differentiation between erosional and corrosion flutes has been omitted, because, especially with flutes on lateral walls, they cannot always be identified correctly. The new symbol can be rotated; if the semicircle is on top, it shows a flute on the ceiling, etc.

Air draught: This is a well known symbol. It should always include the date of measurement. The symbol now uses always two feathers.

The date of measurement should be written in the standard dd-mm-yyyy format.

Ice / snow / firn: The old star symbol used for snow has not been satisfactory for quite some time as it is very time-consuming to draw and the ground structure cannot be shown. Added to this, it can easily be mistaken for the crystal symbol. The old symbol for ice is confusingly similar to true gradient lines.

Taking all this into consideration we agreed on the following solution: Snow is transformed to firn and subsequently to ice. By morphology and composition all three substances are the same, therefore it should be represented by the same symbol. The one that has been chosen is easy to draw, shows the ground structure and cannot be confused.

The date of measurement should be written in the standard dd-mm-yyyy format.

Calcite curtains: The presented solution is not easily understood at first sight but seems to be the best (alternatively you draw the curtains into your map).

Helictites: This symbol is as eccentric as the formation itself and is therefore easily understood.

Straws: This symbol does not need any further explanations.

Crystals: For reasons of international understanding the letters identifing the minerals should be avoided, first because correct mineral identification is often not as easy as it may seem, and second because a $\mathrm{C}$ for calcite is an $\mathrm{K}$ in German and a \# in Chinese.

In general we do not recommend the use of letters as symbols on the actual map. The resulting babylonic confusion can be lethal for the understanding.

Flowstone: Often this or a similar symbol is also used for clay (see there).

Moonmilk: To avoid mistaking this symbol for the guano symbol an additional bow has been added to the usual $\mathrm{m}$.

North: On several maps information on declination is missing or is incomplete which makes the calculation of geographic north almost impossible. Beside the normal North arrow one must specify whether one relates to geographic, magnetic, or cartographers north. If one is relating to magnetic north the date of measurement must be mentioned.

Blocks / debris: as before. The size can be modelled on the reality.

Pebbles: as before. The size can be modelled on the reality.

Clastic sediments: Sand, silt, clay and humus: With the exception of humus this group is a sediment whose grain size and therefore names depend on the velocity of current of the carrying water. In flowing water sand is deposited whereas in standing water clay is deposited. In contrast to this the flowstone (see there), which is a chemical precipitchation, does not represent the velocity of flow but the chemical equilibrium.

As flowstone occurs quite frequently a special symbol needed to be found. The small parallel 


\section{Cave Symbols - The official UIS Symbol List (State 1999 - voted by the national delegates)}

\begin{abstract}
Cauliflowercalcite -
Disk

\section{Anostomosen -}

Karren
\end{abstract}

\section{Plan}
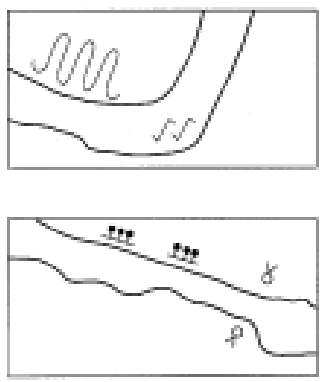

Bones

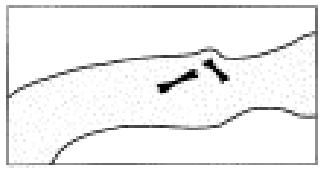

Human Activity

(artwork, drawing, pottery, old mining sites, human bones, ...)
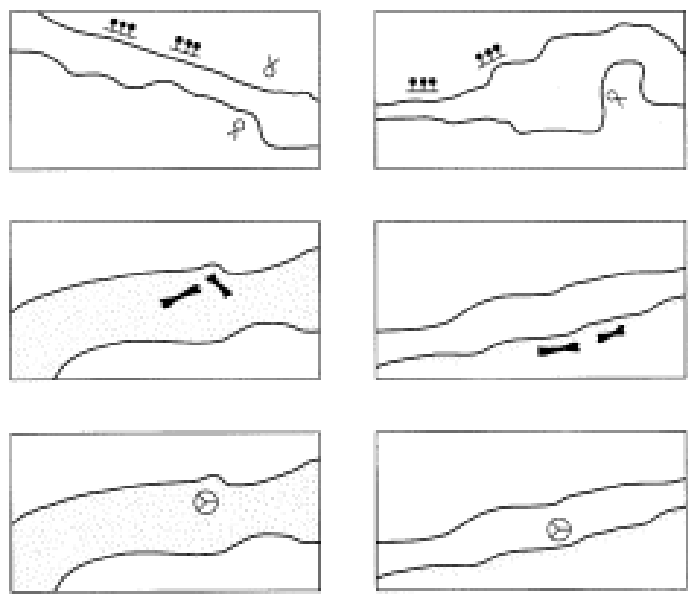

Height of a room

(height in meters)

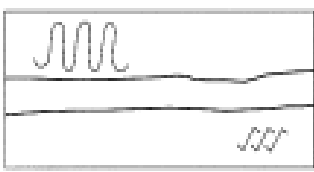

\section{Section}

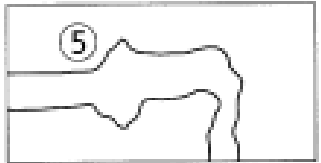


Cauliflower-calcite / discs: These two symbols for calcite are of a regional importance and can be quite useful.

Bones: This symbol does not need any further explanation

Human activity: This symbol is used for man-made changes and/or relicts in caves, including e.g. artwork / drawing / pottery / old mining sites / human bones. Preferably, it will be used for historic/prehistoric changes.

\section{UIS WORKING GROUP "TOPOGRAPHY AND CAVE DRAWING"}

This working group results from the "International Meetings on Subterrainean Topography" that began to verify and standardize already the existing conventional signs. The results are the official UIS symbol list presented here. During this work we have been faced with many other linked problems, such as:

- the use of computer software to draw plans (CAD and DTP-Packages)

- standardising the line thicknesses

- choosing a standard set of colours (in view of the progress of computer plans)

- trying to establish a worldwide standard of precision and accuracy

This will be done as a working group within the UIS Informatics Commission and in close liason with the International Geographical Union and other institutions. The aim of the working group is to establish a set of international standards in order to make maps readable for everybody. Interested people are invited to contact the chairman and author of this article.

\section{Many thanks to our helping colleagues:}

J.P. Aulas, G. Ferrari, V. Grandjean, L. Marusic, P. Matthews, I. Mercolli, N. Ruder, M. \& J.L. Regez, Y. Weidmann, Wookey, R. Zeleznjak.

\section{REFERENCES}

Dériaz P., 1991: Compte-rendu de la Rencontre Internationale de Topographie. - Actes du 9e Congrès National de la SSS, Charmey 1991, 213-216.

Fabre et al., 1978: Signes spéléologiques conventionnels. - UIS / AFK, 44 p.

Grossenbacher Y., 1992: Höhlenvermessung. - SGH-Kurs Nr. 4, 105 p.

Müller R., 1980: Symbole für Höhlenpläne. - Beiträge zur Höhlen- und Karstkunde in Südwestdeutschland, 22, 1980, 3-32. 